FACTA UNIVERSITATIS

Series: Linguistics and Literature Vol. 18, No 2, 2020, pp. 195-205

https://doi.org/10.22190/FULL2002195I

Original Scientific Paper

\title{
MOTION VERBS IN PERSIAN AND ENGLISH: A FRAMENET-BASED CONTRASTIVE ANALYSIS
}

UDC 811.111'367.625:811.222.1'367.625

\section{Zolfa Imani, Rezvan Motavallian}

\author{
University of Isfahan, Iran
}

\begin{abstract}
The current research aims at exploring and comparing the semantic frames of motion verbs in English and Persian. In pursuit of this goal, the novel Animal farm by $G$. Orwell (1945) was selected and compared with its Persian translation, Qale heyvanat (Atefi, 2010). The sentences including motion verbs were primarily extracted from the novel and then a comparison was made between each English sentence and its Persian counterpart. Afterwards, the semantic frames of the English and Persian motion verbs were obtained from the FrameNet database. It should be noted that when the motion verbs in English had an equivalent which could be interpreted in a different way in Persian, the Persian verb was searched for in one of the most reliable Persian to English dictionaries-Persian to English Dictionary (Aryanpur and Aryanpur, 2007). We searched for its English equivalent and then the newly obtained English verb was searched in FrameNet for the semantic frame. When comparing the semantic frames of the motion verbs in the two languages examined, we concluded that motion events in English and Persian were expressed through miscellaneous motion verbs each of which involves a semantic frame peculiar to it. Likewise, the frames may be similar or different crosslinguistically in case of semantic differences, or they might be pragmatically similar.
\end{abstract}

Key words: FrameNet, motion verbs, Persian, English, semantic frame.

\section{INTRODUCTION}

FrameNet ${ }^{1}(\mathrm{FN})$ is a project developed by the International Computer Science Institute (ICSI) and the Linguistics Department at the University of Berkeley. The project aims to describe the frame semantics of a large number of English words (Baker et al. 1998). FN is defined as a project for collecting a linguistic corpus of words, which connects lexical elements and semantic frames (Fillmore et al. 2004).

Submitted September 9, 2019; Accepted March 11, 2020

Corresponding author: Zolfa Imani

University of Isfahan, Iran

E-mail: zolfa.imani.1985@gmail.com

${ }^{1} \mathrm{http}: / /$ framenet.icsi.berkeley.edu 
Within the framework of Frame Semantics (Fillmore 1977, Fillmore 1982, Fillmore 1985), the study of Persian motion verbs has not yet been initiated. Frame Semantics Theory (FST) is the building block of FN, a research project in computational lexicography, a valuable lexical resource for the contemporary English language. It also provides users with both semantically and syntactically annotated sentences from which some useful information in relation to the valency of each word is extractable. FN analyzes LUs, so that their valencies are described. For instance, a frame such as Motion refers to a situation where theme moves from source, paves the path and finally arrives at goal (Petruck 1997). Example (1) shows an LU within the Motion frame in Persian:

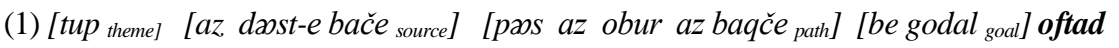

ball from hand of child after from passing of garden to hole fell $3^{\mathrm{RD}} \mathrm{pr}$. sing.

'The ball fell into the hole from the child's hand after passing through the garden'.

In (1), the bolded word oftad (meaning fell) is regarded as an LU in the Motion frame. The subscripts theme, source, path, and goal are called Frame Elements (FEs), the components of which are represented in brackets. Additional explanations about FEs are provided in section 1.1 .

\subsection{Frame Elements (FEs)}

As for FEs, it should be noted that in FrameNet they are classified into two groups: a) Core Elements (CE) and b) Non-Core Elements (NCE) (FN Database). Table 1 represents the two classifications of Motion frame:

Table 1 Core and Non-Core Frame Elements of Motion frame

\begin{tabular}{cc}
\hline Core Elements $=$ CE & Non-Core Elements = NCE \\
\hline Direction & Carrier \\
Distance & Containing-event \\
Goal & Degree \\
Path & Directive \\
\hline Source & Duration \\
\hline Area & Frequency \\
\hline Theme & Iterations \\
\hline------- & Manner \\
\hline------ & Path-shape \\
\hline----- & Place \\
\hline------ & Purpose \\
\hline----- & Result \\
\hline------ & Speed \\
\hline---- & Time \\
\hline
\end{tabular}

According to the table above, there are seven components or elements in Motion frame which are considered core since each is an indispensable part of a motion process. The number of NCEs is much larger than that. However, this is not always the case. Namely, there are some concepts in the frames whose number of NCEs is fewer than or equal to that of the CEs. 
In FN, in front of some FEs, there is a sentence the underlined part of which is relevant to the element itself. For instance, in Motion frame, and in front of Goal, which is one of the FEs, there is the following sentence:

(2) The car MOVED into the slow lane.

In this sentence, the underlined part into the slow lane is marked as Goal in FN. This FE, by definition, is the location the Theme ends up in. Therefore, the noun phrase the car is the Theme and the prepositional phrase into the slow lane is the Goal. In FN, the verbs in each sentence relevant to FEs are marked by small capitals, as the verb MOVED in (2).

\subsection{Motion Event and Motion Verbs}

Verbs belong to one of the grammatical categories considered the building blocks of sentences. These linguistic elements have been examined by linguists and grammarians in various approaches. Motion verbs have also been widely studied. Before we describe what motion verbs are and how they are classified in FrameNet, we should first describe the motion event and its relevant components.

Motion is considered one of the fundamental concepts of cognition. Talmy (2000a: 8) defines motion events as follows: "an event of motion or location - together with a 'Coevent' that relates to it as its Manner or Cause, all within a larger 'Motion situation'". He believes that motion event consists of four major components:

a) Figure: the object which is considered as moving or located with respect to another object.

b) Motion: the moving or located state which one object is considered to be in with respect to another object.

c) Path: the respect with which one object is considered as moving or located to another object.

d) Ground: the object with respect to which the figure is considered as moving or located.

The following example illustrates the aforementioned components (Talmy 2000b):

(3) The bottle moved into the cove.

[Figure] [Motion] [Path] [Ground]

The presence of an event as a cognitive structure and its specific conceptual structure can be regarded as a universal linguistic property. However, it seems that languages belong to a binary category based on a pattern in which the conceptual structure of the event is syntactically realized. This typology consists of a core schema which is expressed either by the main verb or by a satellite. The satellite is a grammatical category of any structure, except for the nominal complement or the prepositional phrase, which is the sister of the verb. This satellite, which can be a bound affix or a free word, may contain all the following grammatical forms: verb particles, verbal prefixes, verbal complements, incorporated nouns, as well as polysynthetic affixes. The languages that form the core schema on the verb are known as verb-framed languages, these include the Romance, Semitic, Japanese, Tamil, Polynesian, Bantu, and some varieties of the Mayan languages. By contrast, languages which encode the core schema on the satellite are named satellite-framed languages, among which the Indo-European languages can be found, with the exception of the Roman languages, as well as the Finno-Ugric, Chinese, Ojibwa, and Warlpiri languages. Although the core schema in satellite-framed languages is largely expressed by the satellite element itself, it is often also 
expressed by the satellite along with a preposition, or sometimes merely by the preposition. Such a preposition consists of an adpositional system and nominative inflection, and sometimes consists of a structure which includes a locative noun (Talmy 2000b: 221-222).

In Persian and other languages, Motion verbs have been examined from different perspectives. In Persian, relevant research is found in Eslamipour and Sharafzadeh (2018), Rezaei and Diyanati (2017), Shahhoseini et al. (2017), Akhavan et al. (2017), Zeddari (2016), Mesgarkhooei (2014), Hamedi Shirvan and Sharifi (2013), Azkia (2012), Feizabadi and Pado (2012), Babai (2011), Golfam et al. (2012) and Amouzadeh and Soltani (2011). In other languages, Verkerk (2015), Abdulrahim (2013), Lindesey (2011), Maalej (2011), Cifuentes-Ferez (2010) and Berthele (2004) are among the most outstanding works on motion verbs. However, none of the abovementioned studies in Persian has investigated motion verbs within FN.

The significance of this study is to concentrate on finding the answers to the following questions:

1) Which frames express motion events in Persian and English?

2) Are those frames the same or different cross-linguistically?

The method employed in the present research involves extracting sentences composed of motion verbs from the story Animal farm (Orwell, 1945) and making comparison between the verb in each sentence with its Persian counterparts in the translation Qale Heyvanat by Atefi (2010). It should also be noted that from the sentences with identical motion verbs, only one sentence was chosen for comparison with its Persian equivalent. At last, we obtained 50 sentences with multiple motion verbs, out of which we chose 20 to discuss in this paper. Furthermore, the motion verbs of each sentence were looked up in the FrameNet for its semantic frame. Ultimately, the semantic frame of each English motion verb was compared to that of the Persian equivalent.

\section{DISCUSSION}

In this section, we present some of the sentences randomly selected from among the whole data. We shall also discuss our findings and analyze the results:

1) He is too weak to pull the plough.

2) He cannot run fast enough to catch rabbit.

3) Every drop of it has gone down the throats of our enemies.

4) He lurched across the yard.

5) He kicked off his boots at the back door.

6) He drew himself a last glass of bear.

7) He made his way up to bed.

8) Before long, the other animals began to arrive.

9) The pigeons fluttered up to the rafters.

10) They came in together, walking very slowly.

11) God had given him a tail to keep the flies off.

12) Our usefulness has come to an end.

13) But no animal escapes the cruel knife in the end.

14) So that future generations shall carry on the struggle.

15) No argument must lead you astray.

16) Four large rats had crept out of their holes.

17) No animal must ever wear clothes. 
Before elaborating on the data collected, some points need to be observed. Since in each of the verbs cited above the motion components are contained explicitly or implicitly, they have been purposefully extracted from the main body of the text. The verbs kick off in (5) and wear in (17) can be distinguished as two examples where motion components are explicitly or implicitly stated. In (5), the Figure is the boot, the way through which the boot is put at the back of the door is the Path, the act of kicking is the Motion and the back door itself is the Ground. In (17), the Figure refers to the clothes which are not going to be worn. The Path is the way passed by the clothes from the outside of the body to the surface of it. The Ground is the body and the Motion refers to the act of wearing.

As can be seen, sentences (1) through (17) have motion verbs, but no two sentences have identical verbs. Furthermore, in some sentences, the motion verb is in the form of the infinitive, whereas in some others, it is finite. As an example, sentence (8) can be described as the one in which the motion verb is a verb preceded by the main verb, whereas in (9) the motion verb is the main verb. In addition, the number of such constituents is so large that we could select only one token. In what follows, we present Persian equivalents of each of the English sentences above:

$$
\begin{aligned}
& \text { 1. ضعيف تر از آن است كه كاو آهن بكثد. }
\end{aligned}
$$

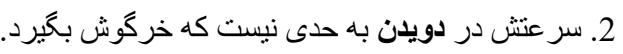

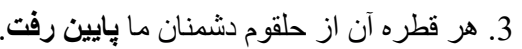

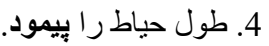

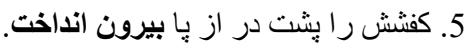

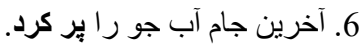

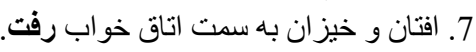

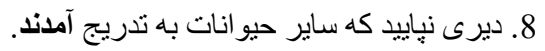

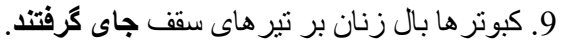

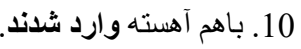

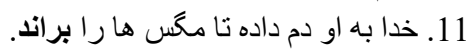

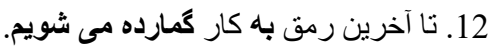

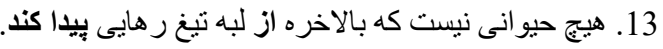

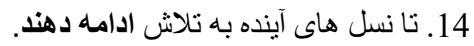

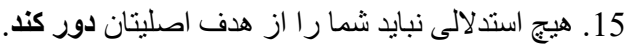

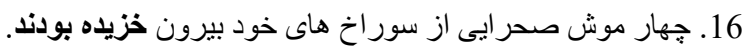

$$
\begin{aligned}
& \text { 17. هيج حيو انى نبايد لباس بيوشند. }
\end{aligned}
$$

The Persian sentences from 1 to 17 are the equivalents of the English sentences cited above. In Table 2, each English motion verb alongside its Persian equivalent will be provided; in Table 3, the semantic frame of the motion verbs in English will be tabulated. Afterwards, we will discuss the comparison and argumentations. It should be noted that the English motion verbs as well as their Persian counterparts are in their infinitive forms for the sake of citation form. 
Table 2 English motion verbs and their Persian equivalents

\begin{tabular}{|c|c|c|}
\hline English Motion Verbs & Persian Equivalents & Phonetic forms \\
\hline Pull & كشيدن & kefidæn \\
\hline Run & 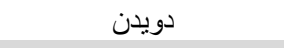 & dævidæn \\
\hline Go & رفتن & ræftæn \\
\hline Lurch & بيمودن & pejmudæn \\
\hline Kick off & بيرون انداختن & birun ændaxtæn \\
\hline Draw & يُ كردن & por kærdæn \\
\hline Make up & رفتن & ræftæn \\
\hline Arrive & آمدن & amædæn \\
\hline Flutter up & جاى كرفتن & dzaj gereftæn \\
\hline Come/Walk & و وارد شدن & vared Jodæn \\
\hline Keep off & راندن & randæn \\
\hline Come to an end & كمارده شدن & gomarde fodæn \\
\hline Escape & رهايى بيدا كردن & ræhaji pejda kærdæn \\
\hline Carry on & ادامه دادن & edame dadæn \\
\hline Astray & دور كردن & dur kærdæn \\
\hline Creep & خزيدن & xæzidæn \\
\hline Wear & ليوشيدن & puJidæn \\
\hline
\end{tabular}

Table 3 Semantic frames of English motion verbs

\begin{tabular}{cc}
\hline English Motion Verbs & Semantic Frames \\
\hline Pull & Cause-motion \\
Run & Cause-motion; Self-motion; \\
Fo & Fluidic-motion \\
Lurch & Motion \\
Kick off & Self-motion \\
Draw & Undressing \\
Make up & Cause-motion \\
Arrive & ------- \\
Flutter up & Arriving \\
Come & Body-movement \\
Walk & Motion \\
Keep off & Self-motion \\
Come to an end & ------- \\
Escape & Process-end \\
Carry on & Activity-ongoing \\
Astray & ------- \\
Creep & Self-motion \\
Wear & Wearing \\
\hline
\end{tabular}


First, it ought to be mentioned that the Persian equivalents presented in Table 2 are taken from the translation text used as the sample. In other words, they are not the exact equivalents of the English verbs, which may be found in English to Persian dictionaries. For instance, sentence (8) is the example of the translation of the expression began to arrive into be tasdrids amasdan ('gradually they came'), in which the headword in Persian is amandand and the expression be tandrids is an adverb; however, the verb amadannd has been taken as the equivalent of arrive. The similar case is in (10), in which there are two verbs in sequence, i.e. came in and walking in the Persian translation: vared fodand (=they entered). In fact, the translator attempted to provide a verb such as vared fodann (=to enter) along with an adverb like aheste (=slowly) for the expressions came in and walking very slowly.

The analysis of 17 sentences presented above indicates that there are five sentences $(7,8,10,11$, and 13) the translations of which are different from the literal meaning of the English versions. In such cases, what made the translator choose such equivalents most probably is in line with her point of view, which is concerned with cultural and conceptual differences between the speakers of the two languages. Finally, it should be determined whether the semantic frames the verbs in such cases evoke are also different or not.

Taking the content of Table 3 into consideration, it is evident that there are three verbs for which no semantic frame was defined: make up, keep off and lead astray. Moreover, for some verbs, there is more than one frame, such as for run and escape. Another point to be noted, excluding the five verbs mentioned above, the other verbs, in English and Persian, signify the same semantic frame. More precisely, the semantic frame which the verb run, for example, evokes is the same as the one the verb davidan evokes in Persian. Therefore, what should be explored here is relevant to the investigation of those five verbs, which are not the exact synonyms of each other.

We should explore whether there is any association between the semantic frames of the equivalents selected by the translator on the one hand and those of the English versions on the other hand. As for those verbs with no semantic frames, their synonyms could be taken into account. For instance, for lead astray there are multiple verbs for which FrameNet specifies semantic frames, as presented in Table 4. The same applies to other verbs, i.e. to make up and keep off, as illustrated in Tables 5 and 6 respectively. In what follows, we will present the three aforementioned verbs alongside their synonyms and semantic frames:

Table 4 Synonyms and semantic frames for 'lead astray'

\begin{tabular}{ccc}
\hline Verb & Synonyms & Semantic Frames \\
\hline & Off the right track & ------ \\
lead astray & Off the mark & ------ \\
& Off the subject & ------ \\
& Amiss & ------ \\
& Lost & ------ \\
\hline
\end{tabular}


Table 5 Synonyms and semantic frames for make up

\begin{tabular}{|c|c|c|}
\hline Verb & Synonyms & Semantic Frames \\
\hline \multirow{15}{*}{ Make up } & Form & $\begin{array}{l}\text { Coming-to-be; } \\
\text { Reshaping; } \\
\text { Creating }\end{array}$ \\
\hline & Compose & $\begin{array}{l}\text { Text-creation; } \\
\text { Behind-the-scenes; } \\
\text { Activity-prepare }\end{array}$ \\
\hline & Comprise & ------- \\
\hline & Constitute & Being-in-category \\
\hline & Invent & $\begin{array}{l}\text { Coming-up-with; } \\
\text { Achieving-first }\end{array}$ \\
\hline & Coin & Achieving-first \\
\hline & Concoct & Cooking-creation \\
\hline & Construct & Building \\
\hline & Create & $\begin{array}{c}\text { Intentionally-create; } \\
\text { Cause-to-start; } \\
\text { Creating }\end{array}$ \\
\hline & Devise & Coming-up-with \\
\hline & Dream up & ------ \\
\hline & Formulate & Coming-up-with \\
\hline & Frame & Encoding \\
\hline & Originate & $\begin{array}{l}\text { Achieving-firat; } \\
\text { Origin }\end{array}$ \\
\hline & Call it quit & ------- \\
\hline
\end{tabular}

Table 6 Synonyms and semantic frames for keep off

\begin{tabular}{ccc}
\hline Verb & Synonyms & Semantic Frames \\
\hline & Hold off & Holding-off-on \\
& Stave off & Preventing-or-letting \\
& Ward off & ------ \\
\hline \multirow{2}{*}{ Keep off } & Rebuff & Respond-to-proposal \\
& Repel & Repel; \\
& Repulse & Stimulate-emotion \\
& Rebut & ------ \\
\hline
\end{tabular}

As illustrated in Tables 4 to 6 , the distribution of semantic frames among the verbs is noteworthy. Surprisingly, it is noticeable that no semantic frame has been defined even for the synonyms of the verb lead astray. Indeed, no Lexical Units such as the expressions in Table 4 exist in the FrameNet database. As a result, no semantic frame was defined. It should also be noted that the FrameNet rarely specifies any semantic frame for phrasal verbs and idiomatic constructions. 
As for make up, it ought to be said that for the synonyms of the verb, the maximum number of semantic frames has been determined by the database, as the number of the synonyms as Lexical Units is larger than that of the two other verbs.

Excluding the items comprise and call it quit, other synonyms of make up evoke at least one semantic frame and at most three semantic frames, as shown in Table 5.

Finally, the verb keep off have synonyms which are both lexical and phrasal verbs. Nevertheless, it is interesting that despite the fact that the FrameNet hardly provides any semantic frame for phrasal verbs, as already mentioned, for the phrasal verbs considered the synonyms of keep off, two semantic frames are defined for hold off and stave off, but no frame for rebut and repulse.

Comparing the frames the three verbs discussed above evoke with the frames evoked by their Persian equivalents, it becomes obvious that the verbs in the two languages can be pragmatically interpreted in similar ways despite their difference in relevant Lexical Units or as semantic frames. In addition, it is worth noting that although there were no Lexical Units or semantic frames for verbs lead astray, make up and keep off in the FrameNet, it does not mean that these verbs fail to evoke any semantic frame. It is rather a limitation in the FrameNet, which can probably be solved in the future. Furthermore, if these three verbs lacked semantic frames, the translator would not have been able to interpret them or to choose any equivalent for them. The translator's capability in choosing the verbs or any linguistic expression for all the motion verbs especially the three verbs confirms that even the verbs lead astray, make up and keep off evoke semantic frames even though they are not specified in the FrameNet.

\section{CONCLUSION}

After contrasting the English novel Animal farm to its Persian translation Qale heyvanat in search for the semantic frames evoked by the motion verbs in the two languages, we can conclude that lexical motion verbs, phrasal verbs and idiomatic expressions with motion verbs can evoke the same semantic frames, since they can be semantically and pragmatically interpreted even if they are not equivalent. Additionally, through such a contrastive analysis, it can be clarified that the FrameNet database has a certain kind of limitation since semantic frames for some lexical and phrasal verbs are not defined. In conclusion, the two questions we posed in this study reveal that motion events in English and Persian may be expressed through diverse motion verbs with distinct semantic frames.

\section{REFERENCES}

Abdulrahim, Dana. 2013. A corpus study of basic motion verbs in Modern Standard Arabic. A thesis submitted to the Faculty of Graduate Studies and Research for the Degree of Doctor of Philosophy. Edmonton Alberta.

Akhavan, Niloofar. et al. 2017. Expression of motion events in Farsi. Language Cognition and NeuroScience. Vol. 32, 792-804.

Amouzadeh, Mohammad \& Reza Soltani. 2011. Ruykærdi shenaxti be chand mæ'nayi: Motale-ye moredi-e fe'le hærkæti-e Aværdæn (In Persian): A cognitive approach to polysemy: A case study of motion verb "Aværdæn”. The Series of Articles of the 3th Conference of Semantics, pp. 233-256. Teheran: Neviseh Parsi Publishing.

Azkia, Neda. \& Farhad Sasani. 2012. Vazhgani shodegi dær fel-ha-ye hærkæti-e Farsi: Olguei tazeh (In Persian): Lexicalization in Persian motion verbs: a new model. Mæjæle-ye Zæban va Zæban Shenasi (Journal of Language and Linguistics in Persian). Spring \& Summer 2012. 
Babai, Hadjar. 2011. Lexicalization of motion event in Persian. Theory and Practice in Language Studies. Vol. 1. Issue 2.

Baker, Collin. F., Charles J. Fillmore \& John B. Lowe 1998. The Berkeley FrameNet Project. Procedeengs of the $17^{\text {th }}$ International Conference on Computational Linguistics. Vol. 1, pp. 86-90.

Berthele, Raphael. 2004. The typology of motion and posture verbs: A variationist account. In Bernd Kortmann (ed.): Dialectology meets Typology. Dialect Grammar from a Cross-Linguistic Perspective. Berlin/New York, pp. 93-126.

Cifuentes-Ferez, Paula. 2010. The semantics of the English and the Spanish motion verb lexicons. In Review of Cognitive Linguistics. October 2010.

Eslamipour, Najmeh. \& Mohammad Hossein Sharafzadeh. 2018. Moqayeseye æf’al-e hærkæti dær do zæban-e Farsi væ Engelisi æz didgah-e shenaxti væ rædeshenaxti (In Persian): Comparison of motion verbs in Persian and English languages: A cognitive and typological approach. Zæban Pæzhuhi Journal. Al-Zahra University.

Feizabadi, Parvin Sadat. \& Sebastian Pado. 2012. Automatic identification of motion verbs in WordNet and FrameNet. Proceedings of KONVENS, Vienna, September 19, 2012.

Fillmore, Charles. J. 1977 a. The case for case reopened. In P. Cole, \& J. Sadock, Syntax and Semantics 8: Grammatical Relations, pp. 59-81. New York: Academic Press.

Fillmore, Charles. J. 1977 b. Scenes and frames semantics. In A. Zampolli, Linguistic Structures Processing. Fundamental Studies in Computer Science 5, pp. 55-81. Amesterdam: North Holland.

Fillmore, Charles. J. 1977 c. Topics in lexical semantics. In R. W. Cole, Current Issues in Linguistic Theory. Bloomington: Indiana University Press.

Fillmore, Charles. J. 1982. Frame semantics. The Linguistic Society of Korea: Linguistic in the Morning Calm, 65-173.

Fillmore, Charles. J. 1985. Frames and the semantics of understanding. Quaderni di Semantica 6, 222-254.

Fillmore, Charles. J., Collin F. Baker, \& Hiroaki Sato. 2004. FrameNet as a "Net". Proceddings of LREC, Vol. 4, pp. 1091-1094. Lisbon: ELRA.

Golfam, Arsalan. et al. 2012. Mæfhum sazi-ye af'al hærkæti-ye bæsit-e zæban-e Farsi: Ruykærdi shenaxti (In Persian): Coceptualization of simple motion verbs in Persian: A cognitive approach. Fæslname-ye Motale'at va Guyeshha-ye Gharb-e Iran (Journal of Studies and Dialects of Western Parts of Iran in Persian). No. 1. Pp. 103-122.

Hamedi Shirvan, Zahra. \& Shahla Sharifi. 2013. Bærresi-ye rædeshenaxti-ye mæqule-ye qæmær dar saxt-e ruydadi-ye af'al-e hærkæti dar zæban-e Farsi (In Persian): Typological study of satellite in event structure of motion verbs in Persian. Fæslname-ye Jostarha-ye Zæbani (Journal of Linguistic Inquiries in Persian), pp. 71-89.

Maalej, Zouheir. 2011. Motion events in Arabic: Implications for verb-framed and satellite-framed languages. Conference Paper, ICLC 11, Language, Cognition, Context. King Saud University, Riyadh, KSA.

Mesgarkhooei, Maryam. 2014. Baznemud-e mæsir dær af'al-e hærkæti-e Farsi (In Persian): The representation of path in Persian motion verbs. In Vizhe Name-ye Name-ye Farhangestan. No. 9, pp. 74-92.

Orwell, George. 1945. Animal farm: A fairy story. Harcourt, Brace and Company.

Petruck, Miriam. R. L. 1997. Framing motion in Hebrew and English. In R. Rossini Favretti (ed.), Frames, Corpora and Knowledge Representation. Bologna: Bolonia University Press, 43-51.

Rezaei, Hadaegh. \& Masoumeh Diyanati. 2017. Hærkæt-e Xiali dær zæban-e Farsi: bærxi vizhegi-ha væ mæhdudiæat-ha (In Persian). Fictive motion in Persian: Some properties and constraints. In Pæzhuheshhay-e Zæban Shenasi Journal. Vol. 9, Issue 1, No. 16.

Shahhoseini, Faegheh. et al. 2017. Bærresi-ye gozærai-ye fe'lha-ye hærkæti dær zæban-e Farsi (In Persian): Study of transitivity of motion verbs in Persian. Do Mahname-ye Elmi-Pazhuheshi-ye Jostarha-ye Zæbani (Journal of Linguistic Inquiries in Persian). No. 7, pp. 117-136.

Talmy, Leonard. 2000 a. Toward a cognitive semantics. Vol. I. Cambridge: MIT Press.

Talmy, Leonard. 2000 b. Toward a cognitive semantics. Vol. II. Cambridge: MIT Press.

Verkerk, Annemarie. 2015. Where do all the motion verbs come from?The speed of development of manner verbs and path verbs in Indo-European. In Diachronica. John Benjamins Publishing Company.

Zeddari, Ikbal. 2016. A comparative analysis of locative and directional motion events in english and Arabic. International Journal of Linguistics. Vol. 8, No. 4. Macrothink Institute. 


\section{GLAGOLI KRETANJA U PERSIJSKOM I ENGLESKOM JEZIKU: KONTRASTIVNA ANALIZA ZASNOVANA NA FRAMENET}

Ovo istraživanje ima za cilj da uporedi semantičke okvire glagola kretanja u engleskom i persijskom. Za uzorak smo odabrali roman Animal farm G. Orwella (1945) i uporedili ga sa prevodom na persijski, tako što smo izdvojili rečenice sa glagolima kretanja iz engleskog originala $i$ uporedili ih sa ekvivalentima iz persijskog prevoda. Potom, semantički okviri engleskih i persijskih glagola su dobijeni iz baze FrameNet. Treba napomenuti da onda kada je engleski glagol imao drugačiji semantički ekvivalent, persijski glagol smo pretražili u persijsko-engleskom rečniku Persian to English Dictionary (Aryanpur i Aryanpur, 2007), da bismo našli engleski ekvivalent, a onda smo ekvivalent pretražili u bazi FrameNet radi utvrdivanja okvira. Kada smo poredili glagole kretanja u dva pomenuta jezika, uvideli smo da se kretanje u engleskom i persijskom iskazuje raznorodnim glagolima kretanja koji imaju sebi svojstvene okvire. Takođe, $i$ sami okviri mogu biti različiti, a onda kada se radi o semantičkim razlikama, mogu postojati pragmatičke sličnosti.

Ključne reči: FrameNet, glagoli kretanja, persijski, engleski, semantički okvir. 